\title{
La imagen teológica del cosmos en los albores de la filosofía: la escuela de Mileto (Tales, Anaximandro y Anaxímenes)
}

\author{
Roberto Cañas Quirós*
}

\author{
Recibido: Julio 2011 • Aceptado: Setiembre 2011 \\ RESUMEN
}

En este artículo la teología es la disciplina que vertebra la filosofía cosmológica en sus albores. Así acontece en la escuela de Mileto con Tales, Anaximandro y Anaxímenes, los primeros filósofos. Este pensamiento racional jónico, lejos de que pueda ser catapultado hacia una reflexión sin dioses o mitos, más bien pretende integrarlos como soporte de sus propuestas.

Palabras Clave: Teología, Filosofía, Escuela de Mileto, Cosmología, Cosmogonías míticas, Evolución cósmica, Visión integral.

\begin{abstract}
In this article, the theology is the discipline which includes the cosmological philosophy and its sources. Thus, the first philosophers appear in the school of Mileto with Tales, Anaximandro and Anaxímenes. This rational thought, away from being thrown toward a reflection without gods and myths, it pretends to integrate them all as a support of their proposals.
\end{abstract}

Key words: Theology. Philosophy, school of Mileto. Cosmology, mystic cosmologies. Cosmic evolutions. Integrated vision.

\section{Introducción}

Este escrito versa sobre la visión teológica que en torno al universo trazaron los fundadores de la filosofía griega y que se remonta a la ciudad de Mileto con Tales, Anaximandro y Anaxímenes. Ellos conforman la escuela milesia, por cuanto comparten características

* Posee una maestría en Filosofía. Es profesor catedrático de la Universidad de Costa Rica y la Universidad Estatal a Distancia. Ha escrito numerosos artículos en revistas especializadas y ha publicado libros como Ética y política en los sofistas (2008), San José, Editorial UCR, y El origen de la filosofía y el retorno de los mitos (2011), San José, Editorial UCR. 
comunes como un interés primordial por la teología y las disquisiciones que la fundamentan, en este caso la cosmología y la cosmogonía. Su estupor intelectual frente a la naturaleza los llevó a plantear un principio susceptible de explicar todas las cosas, de qué están hechas y cómo tiene lugar el cambio. El objetivo de estas páginas es no sólo analizar las propuestas que establecieron, sino también proponer una interpretación que se aparta de la erudición tradicional que los avanza hasta los umbrales del pensamiento científico y técnico modernos, incluso ajenos al politeísmo religioso y con tesis puramente racionales. Ese ha sido un estereotipo dentro de los especialistas de la historia de la filosofía, con frecuencia con una mentalidad positivista y con una perspectiva des-teologizada o des-mitificada. La escisión entre mito y razón es algo que debe ser rebatido en la escuela de Mileto y aun en filósofos posteriores. En ese sentido, el mito no está desprovisto de racionalidad, pues éste encierra su propia lógica, sistematicidad, observación, a pesar de estar fundado en creencias, conjeturas, intuiciones o revelaciones. Durante la época griega antigua los mitos no contaban con los rasgos negativos con que fueron tildados posteriormente y que obnubilan la comprensión de la incipiente filosofía. En Homero y Hesíodo, los principales exponentes de la mitología, se encuentran pasajes que, aunque expresados con envoltura poética, serán el germen de la inaugural filosofía. Aunque Tales, Anaximandro y Anaxímenes no hablaron de los dioses como agentes directos y personales de los sucesos, sí partieron de un trasfondo «divino» que subyace en la naturaleza y que la hace posible.

\section{Los inconvenientes en la obra de Aristóteles como fuente principal para la interpretación de los tempranos pensadores}

A partir del siglo VI en adelante, la imagen acreditada del cosmos en el ámbito griego, obedece a elementos religiosos y filosóficos. Cualquier autor presocrático, e incluso posterior como Platón y Aristóteles, compartieron, en líneas extensivas, una noción común del universo. Todos dieron por seguro una esfera cósmica, limitada por el cielo, con la Tierra en su centro, las estrellas fijas en la circunferencia, y el Sol, la Luna y los planetas girando entre ellos. Además, en ciertas partes de ese cosmos existen componentes que se hallan sujetos a cambio y disolución, al estar integrados primordialmente por segmentos que chocan y se destruyen mutuamente; distinto de ellos, existe una sustancia primaria, un «principio» (arché) más puro, 
elevado y perenne que esos contrarios. Por supuesto que en torno a ese esquema general existen diferencias y matices entre los diversos exponentes de la filosofía.

Si se revisa Aristóteles (Metafísica 983b20), puede repararse en la distinción que precisó entre los que explicaron el cosmos de una manera mítica y sobrenatural, los «teólogos» (theologi), y los que aspiraron, con un nuevo viraje, a interpretarlo desde fundamentos rigurosamente naturales, los «físicos» (physici o physiologi). A estos últimos les confiere una innovadora indagación «física», que se inicia con Tales de Mileto y sus discípulos.

Hay que aclarar que la palabra «teología» no fue empleada sino hasta el tiempo de Platón y Aristóteles. Pero eso no fue obstáculo para que en las composiciones de los grandes poetas griegos y en el alba de la filosofía se manifestara una reflexión sobre lo divino. En ese tanto, la «teología» es la disquisición sobre los dioses o lo divino por medio de la razón y la palabra (lógos). El término «teología» aparece por primera vez con Platón (República 379a), cuando se refiere a los «modelos de la teología», los cuales se sustraen al antropomorfismo de Homero y Hesíodo. Son criterios filosóficos en donde la poesía religiosa no puede representar a las divinidades acometiendo acciones indecorosas, ni tampoco cuando éstos se metamorfosean pasando de lo más perfecto a lo menos perfecto.

El punto de vista de Aristóteles arriba citado es que los teólogospoetas representan el pensamiento humano en su tosca fase mitológica. Sin embargo, a partir de los tratados del neoplatónico San Agustín, el concepto teología adquiere un sentido más amplio. En efecto, el obispo de Hipona, basándose en Terencio Varrón, distingue tres tipos de teología (genera theologiae): la mítica, la política y la natural (La ciudad de Dios IV, XXVII; V). La teología mítica abarca el ámbito de las deidades, tal como se halla plasmado por los poetas, y representa un mundo de bellas creencias imaginarias; la teología política es el dominio de la religión oficial del Estado, sus instituciones y el culto; y la teología natural es el terreno de la filosofía, que proyecta la teoría de la realidad de lo divino. Para San Agustín, creyente en una única religión verdadera, sólo la teología natural puede denominarse religión en su auténtica trascendencia. Para el autor De civitate Dei, el punto de arranque de la historia de la teología, en sentido estricto, inicia con la escuela de Mileto. En el Obispo de Hipona el cristianismo es apreciado como universal y no como monopolio de una sola nación. Eso implica que en las fuentes griegas que van de Tales a Anaxágoras, 
se encuentra la primera fidedigna teología. Durante la alborada de la filosofía griega se localiza una genuina teología natural, una comprensión racional de la naturaleza misma de la realidad.

Evidentemente Aristóteles, mucho tiempo después de los autores presocráticos, analiza el giro del mito a la filosofía desde una atalaya lógica y científica que no está presente en esos tempranos pensadores. Tales ejerció su actividad durante la primera mitad del siglo VI a. C. y el estagirita durante la segunda mitad del siglo IV a. C. Por otra parte, Aristóteles encasilló la descripción religiosa del universo en términos de «sofistería (invención) mítica», plasmada «para persuadir a la multitud, y en provecho de las leyes y del bien común» (Metafísica 1000a18, 1074b3). El fundador del Liceo parte de un menosprecio hacia las primitivas formas de disquisición mítica de la naturaleza. Por otra parte Aristóteles liga, hasta cierto punto, el inicial recorrido filosófico con características comunes del pensar mítico. Cuando asevera que la filosofía tiene su germen en la admiración, lo enlaza con el aserto de que «el que ama los mitos es en cierto modo filósofo, pues el mito se compone de elementos maravillosos» (Metafísica 982b18). Sin embargo, la comparación la desenlaza, indicando que la filosofía se refiere al conocimiento o ciencia universal y necesaria, o al descubrimiento de las causas (cuestión que sus predecesores no desentrañaron suficientemente).

Estas acotaciones en torno a Aristóteles no resultan superfluas, pues él constituye la principal referencia antigua sobre la aurora del pensamiento griego. A su obra se incorpora, además, la posterior información doxográfica, a partir de su discípulo Teofrasto. Hay que advertir, entonces, hasta qué punto Aristóteles utilizó las ideas presocráticas para poner de relieve su propia postura y no tanto para efectuar una historia de la filosofía $^{1}$. Esa distorsión surge cuando presenta a los milesios como autores que atisbaron únicamente la causa material de las cosas, pero que desconocieron las causas eficiente, formal y final. Ese enfoque ubica a los primeros filósofos como «naturalistas», es decir, que sondearon la physis, la materia primaria a partir de la cual existen todas las cosas, ya sea cuando éstas se generan o se disuelven, y permanecía ese sustrato inalterable (Metafisica 983b).

Esa perspectiva conduce a que los primeros filósofos fueran

1. Para profundizar este tema puede consultarse la obra de Harold Cherniss (1991). 
individuos preocupados por la cosmología, el estudio del universo de acuerdo con los principios fundamentales que lo integran y no desligado de ello, lo atinente a los fenómenos meteorológicos y todas las formas de vida en la Tierra. Y dentro de la misma cosmología, se subraya la cosmogonía como la explicación sobre la génesis de todas las cosas. El enfoque de Aristóteles recalca una especialización de los primeros filósofos en la rama cosmológica. Pero en la manera en que lo aborda, podríamos entrever que entre ellos se propició, en definitiva, una «torre de Babel» entre sus propuestas.

\section{Tales de Mileto: el Agua, las cosmogonías míticas y los dioses}

Tales de Mileto es el más antiguo filósofo, el pionero en ese campo, aunque según Aristóteles se halla muy cerca de sus antecesores míticos:

En cuanto al número y a la especie de tal principio (arché), no todos dicen lo mismo, sino que Tales, iniciador de tal filosofía, afirma que es el Agua (por eso también manifestó que la Tierra estaba sobre el Agua). Tal vez llegó a esta concepción tras observar que todas las cosas tienen un alimento húmedo y que el calor se produce y se mantiene en la humedad (ya que aquello a partir de lo cual se generan las cosas es el principio de todas ellas). Por eso llegó a esta concepción y también porque todas las simientes son de naturaleza húmeda y el agua es el principio natural de las cosas húmedas. Pero hay quienes consideran que los más antiguos, muy anteriores a la generación actual y primeros en reflexionar sobre los dioses, pensaron así sobre la naturaleza e hicieron a Océano y Tetis padres de la generación. (Metafísica 983b19)

Aristóteles infiere, por su propia cuenta y no por boca de Tales, los motivos por los cuales «tal vez llegó a esta concepción» sobre el Agua. El estagirita, al mismo tiempo, conecta al milesio con las raíces mitológicas. Según Homero, Océano es el dios que mora en los confines de la tierra (Ilíada XIV, 200) y constituye el gran río que retorna sobre sí mismo al rodear toda la tierra (Ilíada XVIII, 399); además, de él y su consorte Tetis, proceden todos los ríos, mares, nacientes y hondos pozos (Ilíada XXI, 195). Otros relatos de sinnúmero de culturas parecen indicar un razonamiento universal de que el agua, el venero generatriz de toda la vida. La sociedad del tiempo de Tales tuvo cierta asimilación de las ideasorientales, principalmente babilónicas y egipcias, aparte de los viajes que solían efectuar estos personajes a aquellos lugares. Estas civilizaciones 
se asentaron sobre las márgenes de ríos como el Tigris y el Éufrates, y el Nilo, que influenciaron su visión religiosa. Para la mitología babilónica la tierra surgió de Nûn, las aguas primordiales, y continuaban estando bajo ella (a lo que también se pliega Tales). También en el poema de la creación, el Enuma Elish, del segundo milenio antes de Cristo, se localizan las primigenias deidades de la humedad: Apsu, las aguas dulces, Tiamat, el mar, y Mummu, las nubes y niebla. El historiador griego Plutarco (Sobre Isis y Osiris 364d), complementa el tema aseverando que los egipcios creen que Homero, así como Tales, aprendieron de ellos que el agua es el principio de todas las cosas. El agua, como pilar de la creación, se encuentra, además, en otra sociedad oriental, la hebrea, a partir del conocido relato que describe «el Espíritu de Dios que se movía sobre las aguas», y que había unas «aguas que estaban debajo del firmamento»y otras «que estaban sobre el firmamento» (Génesis I, 2, 7).

Tales es exhibido por Aristóteles como un prefilósofo, un exiguo racionalista del mito. En ese sentido, no basta con que esta arché material, el Agua, fuese un núcleo permanente frente a las mutaciones, sino que también debía aunarse su posesión de vida o alma (psyché). Es por esto que a los antiguos jonios se los titula «hilozoístas» (de hylé, «materia»; y zoé, «vida»), o, lo que es lo mismo, que la materia de la que está constituido el cosmos es viviente. No existe materia abiótica o inerte y la manifestación de la vida -o alma- no adviene desde fuera, sino que es consustancial a la materia. Esa vivificación del principio material, implica que todas las cosas se muevan. El alma es una potencia impulsora, como lo alega Aristóteles (Acerca del Alma I, 405a19): «Parece que Tales, según comentan, concibió al alma como algo que mueve, si realmente dijo que el imán tiene alma porque mueve al hierro». Este pasaje podría sugerir que el imán y el ámbar al activar el movimiento a la distancia, se funda en que poseen propiedades invisibles al modo de espíritus. A esto el estagirita relaciona el alma con los dioses, los cuales dentro de la mentalidad mítica son causas motrices de las cosas (Acerca del Alma I 5, 411a): «Y algunos dicen que el alma está mezclada en el todo; de ahí también quizá que Tales haya pensado que todo está lleno de dioses». El Agua, el alma y los dioses son tres entidades indesligables en el pensamiento de Tales y no se justificaría su inconexión. En su pensamiento se combina el politeísmo y polidemonismo religioso griego, donde los seres sobrenaturales son los agentes personales que suscitan todos los fenómenos físicos, junto a los vestigios del antiquísimo 
animismo o animatismo, en el que todo está lleno de espíritus. Para la religiosidad griega el cosmos está plagado de dioses: Helios es el Sol, Selene es la Luna, el amanecer es Eos (la Aurora), y las Constelaciones son personajes famosos deificados; nosotros vivimos sobre Gea, la Tierra; en lo subterráneo, en el aire, en los mares y en los bosques pululan toda clase de seres divinos y semidivinos. Tales es hijo de su tiempo y no habría que acelerar en él una inusitada anticipación al pensamiento científico moderno. Las leyendas sobre sus predicciones astronómicas y los conocimientos que poseía sobre este campo, no lo catapultan más allá de su época.

Una anécdota atribuida a otro jonio posterior, a Heráclito, presenta similitud de esa mezcla de lo teológico y filosófico en la aprehensión de la realidad. La historia es que estando él en su hogar, calentándose junto al fuego, se percató de unos visitantes que se hallaban en el umbral de su casa y dudaban en entrar. Entonces les gritó: «Entrad. También aquí hay dioses» (Aristóteles, Partes de los animales I, 5, 645a17). Podría tomarse la frase en correlación con el fuego, su principio de todas las cosas, pero de lo que se trata es que también en su filosofía lo divino, el Fuego como arché, el lógos y el flujo perpetuo son conceptos afines. A la religión dionisíaca Heráclito le debe buena parte de sus sentencias enigmáticas. Por otro lado, su filosofía religiosa fue apreciada hasta tal punto siglos más tarde por los padres apologetas, que lo percibieron como un testigo pagano de la salvación y la escatología cristiana ${ }^{2}$.

En Tales no se puede desvincular su creencia de que la realidad está por doquier poblada de deidades, con su propuesta sobre el Agua como componente cósmico. Sus intuiciones sobre la naturaleza

2. La interpretación cristiana de Heráclito se debe a Clemente de Alejandría e Hipólito, quienes vieron en la idea del «fuego cósmico» heraclíteo, el mismo significado que la justicia divina, el Juicio Final e incluso el Infierno. Otra similitud que captaron fue con respecto al Lógos heraclíteo que se encarna en el alma, como una especie de prefiguración de la Encarnación. También Clemente (Stromateis V, 14) compara el fragmento 34 de Heráclito: «Estúpidos, aunque escuchan son como los sordos. El proverbio los describe: aunque presentes, están ausentes», con las palabras de Jesús: «¿Teniendo ojos no veis y teniendo oídos no oís?» (Marcos $8,18)$. En el fragmento 21 de Heráclito: «Lo que vemos cuando estamos despiertos es muerte, lo que vemos dormidos es sueño", Clemente considera que el apego a la vida terrena es muerte, bajo la expresión «el que halla su vida la perderá» (Mateo 10, 39). En Heráclito el uso del lenguaje simbólico, la paradoja y la parábola impresionó a los autores cristianos, quienes no pudieron dejar de ver las similitudes con Jesús y su mensaje metafórico del grano de mostaza, las simientes esparcidas en diferentes clases de tierra, un viñedo arrendado a unos viñadores incrédulos, o símiles como un tesoro oculto, la levadura, una lámpara o una candela, etc. 
buscan ser un fundamento de su teología.

El universo es percibido por Tales desde los elementos motrices del Agua, el alma, la vida, el automovimiento y los dioses. En una cita de Aristóteles, se puede entrever cómo el Agua es predecesora de Gea, o cómo a partir de un mar primordial surge la Tierra:

Otros sostienen que [la tierra] descansa sobre el Agua. En efecto, conocemos este antiquísimo argumento que dicen que sostuvo el milesio Tales: por ser flotante, [la Tierra] permanece como un leño o algo similar (pues ninguna de estas cosas puede mantenerse naturalmente sobre el Aire, sino sobre el Agua), como si no pudiera argumentarse acerca del Agua que sostiene a la Tierra lo mismo que se dice de ésta. Pues tampoco el Agua puede permanecer naturalmente suspendida, si no está sobre algo. (Del Cielo II 13, 294a)

De acuerdo con la versión de Aecio (I, 3, 1), quien cita a Teofrasto, quien a su vez refiere las consideraciones biológicas emitidas por Aristóteles, apunta que el semen de los animales es húmedo y que las plantas se nutren de la humedad. Además, agrega «que el fuego del Sol, las estrellas mismas y la totalidad del cosmos se alimentan mediante exhalaciones de agua». En otra mención Aecio añade (II 20,9): «Tales dice que el Sol es similar a la Tierra en su naturaleza»; y en otra generaliza al universo en su conjunto (II 13, 1): «Tales dice que los astros son similares a la Tierra, pero inflamados». El milesio pudo apoyarse en creencias populares, pues de acuerdo con Heródoto (II, 25), el Sol «atrae el agua hacia sí» y «también la reserva para sí». La humedad como vapor cálido es la simiente cósmica, por la cual se nutren no sólo los organismos en la Tierra, sino también la incandescencia celeste en un universo viviente.

\section{Anaximandro: la evolución cósmica a partir de lo Infinito como «principio» divino}

Otra visión del cosmos, desde enunciados más especulativos, la presenta el sucesor de Tales, Anaximandro. Para empezar se puede mencionar la referencia de Simplicio, quien a su vez se basa en Teofrasto (Física 24, 13-20):

[Para Anaximandro] el principio (arché) de todas las cosas es lo Ilimitado (ápeiron), y fue el primero que introdujo el nombre "principio». Dice que no es ni agua ni ningún otro de los así llamados elementos, sino una sustancia diferente que es ilimitada, de la cual nacen todos los cielos y los mundos que hay en ellos. Ahora bien, a partir de donde hay generación para las cosas, hacia alli también se produce 
destrucción, según la necesidad; en efecto, pagan la culpa unas a otras y la reparación de la injusticia, de acuerdo con el ordenamiento en el tiempo.

El concepto arché puede entenderse a partir de Aristóteles como 1) punto de partida, 2) causa motriz, y 3) aquello en lo cual todas las cosas desembocan. Por otra parte, Anaximandro se aparta de Tales al postular un sustrato no perceptible como lo Ilimitado, Infinito o Indeterminado, pues el agua no haría posible cualidades de índole de tan distinta constitución como el fuego y la tierra. Esa sustancia para Anaximandro no puede ser algo que sea homogéneo con el resto de entes existentes y que a su vez posea el poder para dar origen a la incalculable vastedad de todos ellos. Según Aristóteles, lo Indeterminado implica una infinitud temporal y no espacial:

Cualquier cosa es un principio o procede de un principio. Ahora bien, de lo Infinito no hay principio, ya que ése sería un límite. Además, como principio, es inengendrado e indestructible, pues lo engendrado alcanza necesariamente un fin, $y$ hay un término para toda destrucción. Por eso, según afirmamos, no hay principio de él, sino que él parece serlo de lo demás, y "abarca todas las cosas y a todas gobierna», según declaran aquellos que no admiten, junto a lo Infinito, otras causas, tales como el Intelecto [Anaxágoras] y la Amistad [Empédocles]. Y esto es "lo divino», pues "es inmortal e imperecedero", como dicen Anaximandro y la mayoría de los filósofos naturales. ( Física III 4, 203b)

La eternidad de ese «principio» en Anaximandro se circunscribe a su cosmogonía transformista. Las cosmogonías griegas, tanto a escala religiosa como filosófica, son «evolucionistas» y no creacionistas. Con ello, no se debe pensar en la teoría científica de Darwin, pues las ideas evolucionistas ya se habían planteado mucho antes que él.

En Hesíodo (Teogonía 116 y ss.) el dios Caos es pre-existente, anterior a Gea, a Urano y a todas las camadas titánicas y olímpicas; es decir, la tierra y el cielo estaban amalgamados en un inicial estado anárquico. Los dioses griegos nunca crearon el cosmos, solo lo ordenaron y ocuparon regiones. Aristóteles hace su propia interpretación (Física IV 8, 208b), cuando sostiene que el Caos involucra el vacío abierto o la confusión anterior a la organización cósmica y es la divinidad más antigua; también es el oscuro, silencioso y desordenado abismo, de donde procede la existencia de todas las cosas. Por tanto, Caos es un «abismo» y no un «cuerpo»; o sea, es un «lugar» en el que están los «cuerpos».

El mundo orgánico de los presocráticos es eterno y autocausado, 
o sea, existe una phýsis que se multiplica a partir de sí misma, no por alguna causa foránea que opere sobre ella. Una disimilitud con el pensamiento religioso hebreo, se subraya con Yahvé, el ser personal, perfecto, santo y distinto de la materia de la que formó el universo y el hombre. En el ámbito griego nunca podría soldar la creencia en una divinidad creadora que, de lo no existente, hiciera lo existente, pues «de la nada, nada se hace» (ex nihilo, nihil fit $)^{3}$. Sin embargo, no hay que figurarse una novedad de creacionismo absoluto en el Génesis bíblico, pues, si bien es cierto entre los hebreos el concepto de "creación» tiene a Dios como único sujeto, esto no significa que en su tradición antigua hubiese una conciencia de que a partir de la nada haya creado todo lo existente. Semejantes abstracciones metafísicas no corresponden con un pueblo cuyo lenguaje y visión del mundo estaba centrado en las cosas particulares.

3. Uno de los más importantes negadores de la creación ex nihilo, fue Epicuro a partir de su física atomista. En su Carta a Heródoto (3839) dice: «Nada nace de la nada; pues todo nacería de todo sin necesidad de gérmenes; y si lo que desaparece se disolviera en el no ser, todo perecería por no existir nada en que poder cambiarse cuando se deshace». Después su seguidor Lucrecio retoma sus ideas, en frases como «ninguna cosa nace de la nada» y de «de la nada nada puede hacerse» (De Rerum Natura I, 150, 156). Más tarde Persio en sus Sátiras repite a Lucrecio.
El judaísmo antiguo no manejó el concepto de una nada absoluta, cuando mucho de una nada relativa que, mediante imágenes como el polvo y el vacío, nunca rebasaban el terreno de lo concreto. Una excepción, pero ya bajo influencia del helenismo, es el libro de los Macabeos (II, 7, 28), donde se declara: «Te ruego, hijo, que mires al cielo y a la tierra y, al ver todo lo que hay en ellos, sepas que a partir de la nada [lo no existente] lo hizo Dios y también el género humano ha llegado así a la existencia».

En la información de Aristóteles arriba citada, se presenta a Anaximandro como el iniciador de una forma de entender el universo de manera teológica y filosófica. Ya se había mencionado el pasaje "pagan la culpa unas a otras y la reparación de la injusticia, de acuerdo con el ordenamiento en el tiempo», en el que lo Ilimitado se asocia con una divinidad equitativa, y como un tribunal otorga justa retribución por las injusticias cometidas. Es el supuesto de un orden racional sobre el mundo, a partir de una superlativa capacidad divina para proporcionar justicia, a fin de que las faltas cometidas se reparen mediante expiaciones. En los poetas antiguos griegos está igualmente presente, a escala religiosa, la idea de divinidades que supervisan las culpas infringidas con el propósito de brindar justicia 
(Hesíodo, Teogonía 38; Solón fr. 3, 16 y 24, 3-5).

Anaximandro se agencia del lenguaje de la épica jónica para caracterizar a su nueva divinidad lo Infinito, como «inmortal e imperecedero», «que nunca envejece», «lo divino», «que gobierna o pilotea» y «que abarca» el universo. El trazo seguido por el milesio después lo continuaron Empédocles asignando ese papel divino a la Amistad (Filía) y Anaxágoras al Intelecto (Noûs).

Aristóteles distingue, sin embargo, a Empédocles y Anaxágoras quienes plantean una causa separada, de los milesios hilozoístas afincados en la concepción de una materia animada auto-genética. Para ellos la arché material al mismo tiempo abarca y compone todas las cosas y es la fuerza directora e inmanente del cambio. Por otra parte, para Anaximandro el ápeiron como arché no sólo posee la condición de gobernar el universo, sino también la categoría de divino. Los vocablos griegos «dios» (theós) o «lo divino» (tò theĩon) son intercambiables, los cuales implican inmortalidad y poder. Extirparle al ápeiron su asociación con los dioses o con los mitos tradicionales, es una postiza modernización ${ }^{4}$.

4. Esa modernización de los milesios y en particular de Anaximandro puede encontrarse en G. Vlastos (1952, 113 y ss.). Una opuesta
En Anaximandro, a partir de lo Infinito surgen, los contrarios que se suceden en la naturaleza. Así lo expone Aristóteles, sin citar explícitamente a Anaximandro:

Tampoco es posible que el cuerpo infinito sea uno y simple, ni el caso de, como dicen algunos, lo que está aparte de los elementos, a partir de lo cual se engendran aquéllos, ni en ningún otro caso. Hay algunos, en efecto, que suponen que eso es lo infinito, y no aire o agua, de modo que los demás elementos no sean destruidos por ser lo Infinito uno de ellos, ya que todos tienen contrariedad entre sí: el aire es frío, el agua húmeda, el fuego caliente; de manera que, si uno de ellos fuera infinito, los otros serían destruidos. Por eso dicen que aquello de lo cual se generan los elementos conocidos es algo aparte. (Física I 5, 204b)

En el cosmos los contrarios son intercambiables, pues hay alternancia de lo caliente y lo frío, de la luz y la oscuridad, de la vida y la muerte, siendo todos ellos distintos de esa arché primigenia. Esa naturaleza distinta del ápeiron con respecto a los elementos, es repetido por Simplicio (Física 479, 30-480; 41, 17-18). Mientras los contrarios se destruyen y re-crean, el ápeiron es imperecedero. Se suma al ápeiron

perspectiva es la de W. Jaeger (1992, 39 y ss.), para quien la asociación entre el ápeiron y lo divino son indisolubles. 
su ausencia de «límites» (pérata). Pero no se trata de una infinitud espacial, pues para los griegos en general cualquier cosa vasta es ilimitada, como la Tierra, el mar o los habitantes de los pueblos (Homero, Ilíada XXIV, 545, XIV 200201, XXIV 776; Odisea XV 79). Se trataría en Anaximandro de una sustancia inmensa, quizás una esfera, que rodea la totalidad cósmica (Aristóteles, Física 203b11).

El ápeiron es no sólo el principio vivo y divino, rector cósmico, sino también el estado primordial de todas las cosas, una mezcla. En esa mixtura los contrarios estaban amalgamados antes de la cosmogonía, para después originarse un proceso de «separación» de éstos (Aristóteles, Física I 4, 187a). Esa infusión pre-cósmica de lo indeterminado, aunque no tenga el barniz mítico-poético, recuerda el dios Caos de Hesíodo, previo a Gea y a toda la estirpe divina. Las más antiguas teogonías nutren a las nuevas especulaciones filosóficas. En Anaximandro el ápeiron es la más perfecta cristalización de lo divino, como sustrato eterno, ilimitado, gobernante y timonel del cosmos, que imprime su sello de justicia y retribución por decreto, y donde cada ser ha sido derivado de él. Pocos griegos como Anaximandro se atrevieron a asignar tanto status a una entidad.
El universo se formó para Anaximandro mediante una «separación» (apókrisis) de los contrarios a partir del ápeiron. Guardando las proporciones, esa separación puede apreciarse también en el Génesis bíblico (I, 4, 6-7 y 9), donde se dice que Dios es el agente separador de los contrarios: «Dijo asimismo Dios: Haya un firmamento o una grande extensión en medio de las aguas, que separe unas aguas de otras. E hizo Dios el firmamento, y separó las aguas que estaban debajo del firmamento, de aquellas que estaban sobre el firmamento». También que Dios «dividió la luz de las tinieblas». Y más adelante se agrega: «Reúnanse en un lugar las aguas que están debajo del cielo, y aparezca lo árido o seco».

Hacia el siglo IV d. C. el autor cristiano Eusebio, Obispo de Cesárea, basándose en compilaciones doxográficas de la obra de Teofrasto, escribió cómo sobrevino el universo para Anaximandro:

Él [Anaximandro] dice que, en el nacimiento de este cosmos, un germen de calor y frío se separó de la sustancia eterna y de él surgió una esfera de llama en torno al vapor que rodea la tierra, [ciñéndolo] como la corteza ciñe al árbol. Cuando aquélla se rasgó y se separó en varios anillos, se originaron el sol, la luna y las estrellas. (DK, A 10) 
La palabra «germen» (gónimon), aunque no se sabe si fue usada por el propio Anaximandro, se refiere a lo que es fértil, susceptible de engendrar, creador, como el huevo, el semen, el embrión o la semilla. La generación cósmica Anaximandro la percibe desde analogías de la vida orgánica o desde creencias populares en el que una especie de limo feraz de las riberas de los ríos, cuando el calor del sol la irradia, emana vida espontánea. En las cosmogonías religiosas también son recurrentes esas comparaciones. De este modo, en los misterios órficos se establece que el universo brotó de un «huevo cósmico», generado por medio de Eros: una vez que su cáscara se rompió, de la mitad superior se levantaron los cielos y de la inferior la tierra (Orph. fr. 70). La acción de lo caliente y lo frío indica para Anaximandro los ingredientes opuestos que procrean la vida cósmica. Lo Ilimitado es una especie matriz recubierta de «corteza» (o membrana) con la que cobija la totalidad del universo y que, durante la formación cósmica, el germen calor-frío se desmembró de él, engendrándose cada cuerpo celeste.

Este desgarro de la piel del ápeiron, por usar un símil en términos de la vida orgánica según la mentalidad de Anaximandro, se produce porque esta arché es algo eternamente viviente, lo cual implica movimiento o auto-causación (kínesis). Las citas que vinculan lo Infinito con el movimiento pueden verse en los siguientes testimonios:

Simplicio, Física 24, 23-25: [ Anaximandro ] piensa que la generación se produce no al alterarse el elemento, sino al separarse los contrarios por obra del movimiento eterno.

Hermias, Ridiculización de filósofos paganos 10: Anaximandro, conciudadano de [Tales], dice que el principio, más antiguo que lo húmedo, es el movimiento eterno, y por éste unas cosas se generan y otras se destruyen.

Simplicio, Física 41, 17-19: El milesio Anaximandro, hijo de Praxíades, propuso como principio una cierta naturaleza distinta de los cuatro elementos, el movimiento eterno de la cual era, decía, la causa de la generación de los cielos.

«Movimiento»y «eterno» no son características incongruentes en Anaximandro, a pesar de que en autores posteriores como Parménides, Platón y Aristóteles se acentuara la inmutabilidad del Ser, de las Formas y del Primer Motor. Ya se había visto que para Tales el Aguaviviente, el auto-movimiento y el alma son conceptos inseparables, por lo que ha de presumirse que para la escuela de Mileto la movilidad no es una condición excluyente 
de lo divino. Así como las estrellas y los planetas para los antiguos poseían un desplazamiento eterno y para el politeísmo imperante los dioses operan en ellos mismos todo tipo de metamorfosis, para Anaximandro el ápeiron posee actividad y transformación. Aunque no se expresa con palabras mítico-poéticas como hiciera Hesíodo cuando se refirió a la generación cósmica como el resultado de apareamientos divinos, en Anaximandro prevalece un zoomorfismo teológico en términos de gérmenes, cortezas o rasgaduras de pieles.

Otra de las propuestas de Anaximandro en la que se registra una espinosa interpretación, es su creencia sobre «ilimitados mundos» (ápeiroi kósmoi) o «ilimitados cielos» (ápeiroi ouranoí). Los pormenores se encuentran principalmente en Simplicio (Física 41, 17-19; 24, 17-18). Estos innumerables cielos o mundos se derivan del primigenio Ápeiron. Por kósmos hay que entender «orden», «conexión armoniosa y bella»; y por ouranós, «cielo», «región cósmica» (como en la mitología donde el universo se divide en la Tierra, el Hades, el Olimpo, los mares, etc.). Esa pluralidad de mundos significa para Anaximandro una teogonía filosófica, que no se basa en un único dios en el firmamento, como el caso de Urano en Hesíodo, sino en una extensión indeterminada de deidades y, por consiguiente, procedentes de esa materia prístina ilimitada. Anaximandro quizás imaginó este ápeiron como una materia viva y divina, que bordea como esfera (la figura de la perfección griega), la totalidad de los ilimitados ouranoi o dioses.

\section{Anaxímenes: el Aire como dios y su impregnación cósmica}

El último representante de la escuela de Mileto es Anaxímenes, quien vivió alrededor de la mitad del siglo VI a. C. y probablemente conoció a Anaximandro. Anaxímenes se circunscribe dentro de la tradición filosófica milesia «monista» (de mónos, uno). Una sola arché es su propuesta y el Aire (aér) es el que instaura ese principio.

A diferencia de Anaximandro y su ápeiron expresado de modo puramente hipotético y en términos de cualidades o sustantivación de adjetivos -lo indeterminado, lo divino, lo inmortal-, Anaxímenes opta por una entidad claramente substancial y que es objeto de experiencia directa. La dificultad de la teoría de Anaximandro es que después de la separación de los contrarios del ápeiron, éste tuvo que haber adquirido «límites», a fin de poderse diferenciar del resto de componentes que integran el cosmos. El Aire, en cambio, puede mantener su carácter de esencia universal, a 
pesar de estar a veces más comprimido o más vaporoso, más tórrido o más gélido.

En los datos que provee Aristóteles (Metafísica I 3, 984a), el Aire de Anaxímenes es un primer principio y pre-existente entre los cuerpos simples, anterior al agua. Esta simplicidad que indica el estagirita sugiere un principio vivificante, de carácter general y no necesariamente el aire atmosférico (que a su vez formaría parte de éste). Al igual que en Tales, el Agua como arché, no equivale únicamente al líquido potable o marino, sino a la humedad universal, que integraría también la esperma, la savia, la sangre, etc.

Un rasgo distintivo entre el mito y la escuela milesia, es que el primero apela a causas particulares (los seres personales divinos) para explicar los hechos singulares, mientras que en los milesios hay una cierta tendencia a dilucidar de manera general los fenómenos. Eso no significa que ambos abordajes sean excluyentes, ni que haya una repentina disipación del mito con respecto a las reflexiones de los milesios. Es en sentido estricto hasta Aristóteles, en que los universales son los verdaderos objetos de conocimiento y sólo la generalización puede llevar a desentrañar las causas (Metafísica 982b).

Para los filósofos griegos uno de los mayores enigmas por resolver es el problema del cambio, del proceso por el cual las mutaciones ocurren. En esa dirección, para Anaxímenes el movimiento y las transformaciones poseen un carácter eterno. Así lo acota Hipólito, el apologeta cristiano del siglo III (Refutación a todas las herejías I, 7, 2): «[El aire] se mueve siempre; en efecto, todas las cosas que se transforman no se transformarían si [el aire] no se moviese».

La elección del Aire de Anaxímenes se afinca en que éste, a pesar de haber sido la materia primitiva, resulta moldeable en diversas manifestaciones y permanece con sus mismas propiedades. La respuesta de Anaximandro de que lo Ilimitado es aquello de lo que todas las cosas reciben su ser y en lo que todas las cosas tienen que disolverse de nuevo, resulta insatisfactorio si se compara con un Aire substancial con un proceso de compactación y enrarecimiento. Para estos efectos, puede verse la explicación que anota Simplicio (Física 24, 28-31):

El aire se diferencia en las cosas particulares por rarefacción y condensación. Al enrarecerse se convierte en fuego, al condensarse en viento, luego en nube, más condensado aún en agua, tierra y piedra; las demás cosas se producen a partir de éstas.

Hipólito (Refutación de todas las herejías I, 7; I, A 7), quien 
se apoya en Teofrasto, ofrece más detalles:

Anaximenes, otro milesio, hijo de Eurístrato, dice que la arché es el aire infinito, del cual procede cualquier cosa que se origine o haya existido en el pasado o exista en el futuro, al igual que los dioses y la divinidad. Todo lo demás está hecho de sus sucesores [vástagos]. El aspecto del aire es como sigue: cuando está al máximo esparcido por igual (uniforme), es inaprehensible a la vista; pero se hace visible, en cambio, por causa del calor y el frío, la humedad y el movimiento. Está en movimiento perpetuo; en efecto, todas las cosas que se transforman no se transformarían si [el aire] no se moviese. Al condensarse y enrarecerse parece diferenciarse; pues cuando se dispersa en el grado más sutil, se genera el fuego. Los vientos, en cambio, son aire que se condensa y del aire se origina la nube por compresión. Al condensarse más, se produce agua; y una mayor condensación aún, tierra. Mientras que las piedras constituyen la forma más condensada de todas. De este modo, los componentes más importantes en el proceso de la generación son contrarios: caliente y frío.

No hay fragmentos de Anaxímenes que revelen las razones que justifican el opuesto proceso de condensación y rarefacción a partir del Aire. Tampoco esclarece si fue, como en Anaximandro, una separación a partir de una mixtura primigenia. Lo que tienen en común ambos autores es una arché de carácter infinito, móvil, con vida y con divinidad. El planteamiento de Anaxímenes no se posa sobre una innovadora teoría científica, pues su pretensión consiste en presentar las bases filosóficas de una teología. El Aire es una especie de divinidad primigenia, cuyos «productos» o «vástagos», al modo de una genealogía mítica, son los elementos engendrados: fuego, agua, tierra, vientos, nubes, piedras y los dioses populares. Después del Aire, todo lo que integra el cosmos son sus descendientes o retoños. En Aecio (I 7, 13) encontramos la afirmación: "Anaxímenes dice que el aire es dios» $\rangle^{5}$.

La mitología de la época de Anaxímenes era consecuente en

5. En 1906 Theodor Gomperz (2000) analiza a los presocráticos únicamente desde la vertiente física, oscureciendo el aspecto religioso. Después John Burnet (1930: 14 y ss.) los interpretó desde un lente anacrónico, señalando que los representantes iniciales de la filosofía eran simples naturalistas o exponentes que «han franqueado la vía de la ciencia, no habiendo nada más que seguir». Según él, estas propuestas derriban radicalmente las creencias y sentimientos religiosos, hasta el punto de mantener una completa independencia con respecto a los cultos populares. Argumenta, además, que el término «dios» carece de un sentido religioso en los presocráticos y que corresponde objetar el yerro de asumir que «la ciencia se deriva de la mitología». Sin embargo, su óptica ha sido bramada a partir del apogeo del positivismo. 
asociar el aire con el aliento vital, la respiración y lo divino. Una de las creencias de las culturas más remotas es que los elementos de la naturaleza son los que fecundan los seres femeninos, sobre todo como súbitas ráfagas de aire que entran en el vientre. En Homero (Ilíada XX, 219 y ss.), Bóreas, el dios-viento del norte, fertilizó a doce de las tres mil yeguas que pertenecían a Erictonio y que solían pacer junto al río Escamandro; y de esa unión, nacieron doce potrancas que podían galopar sobre las espigas de trigo maduras sin romperlas, o sobre la cresta de las olas. También Heródoto (VII, 189), sin contrariar la historia, cita que los atenienses invocaron a Bóreas, quien había hecho a Oritía su esposa, hija de Erecteo, rey de Atenas, para que destruyera exitosamente la flota del rey Jerjes. En otro pasaje de Homero (Ilíada XVI, 149 y ss.), se cuenta que Janto y Balio, los caballos de Aquiles, fueron engendrados por el viento Céfiro, cuando éste fecundó a su madre la yegua Podarga. En época posterior, la autoridad de Homero y el conglomerado de creencias populares condujeron al erudito romano Plinio (Historia Natural IV, 35; VIII, 67), para que dijera que las yeguas españolas podían preñarse simplemente exponiendo sus cuartos traseros al viento. Mientras que Lactancio, el retórico romano converso al cristianismo del siglo
III, en su escrito Sobre la obra de Dios, hace la analogía con la fecundación aérea de la Virgen María por el Espíritu Santo.

Otras representaciones sobre el cosmos posteriores a Anaxímenes se asoman con la religión órfica y los pitagóricos, en donde se lo concibe como un ser vivo, eterno, divino y que respira en el aire o hálito que atrae hacia sí (Aristóteles, fr. 201; Aecio II, 9, 1). Por otra parte, los pitagóricos identificaron el alma con las partículas que hay en el aire o con aquello que mueve dichas partículas -en este caso el alma como motor del cuerpo, que siempre debe estar en sí mismo en movimiento- (Aristóteles, Acerca del Alma 404a). Otros autores del siglo V a. C. como Leucipo y Demócrito, asumieron la existencia de átomos del alma, que equivalen al principio de vida, al ingresar por medio de la inhalación y donde la muerte no es más que el alejamiento de esas finas partículas. La vida se mantiene gracias a la respiración, pues los sutiles, móviles y esféricos átomos del alma se encuentran bajo la tirantez ininterrumpida de la atmósfera exterior, que los despide del cuerpo (Aristóteles De respir. 471b30; Acerca del alma 409a9).

Un filósofo del siglo $\mathrm{V}$ a. C. afín a Anaxímenes, fue Diógenes de Apolonia. Revitalizó la noción de que el Aire era el sustrato cardinal. Pero no sólo se restringió a 
ubicarlo como el origen de todas las cosas, sino que también lo catalogó como el principio del alma cósmica, con un parentesco especial con el alma de todos los seres vivientes. Así lo glosa Simplicio, sustentándose en las palabras de Diógenes:

La humanidad y los demás seres vivos viven por el aire, porque lo respiran, y para ellos es alma y mente simultáneamente.

El alma de todos los seres vivos es la misma, es decir, aire más caliente que el aire del exterior, en el cual vivimos, aunque mucho más frío que el de junto al sol.

En mi opinión, lo que tiene inteligencia es lo que los hombres llaman aire y por él todo se gobierna, y tiene poder sobre todo; porque precisamente es esta sustancia la que sostengo que es dios. (frs. 4 y 5 )

Aquí se revela la idea de que las almas de los seres vivientes son un microcosmos, una fracción que se originó del macrocosmos aéreo. Esa consanguinidad entre el Alma-Aire del universo y nuestra alma-propia, comenta Teofrasto al respecto de Diógenes (De Sensu 42), es porque «el aire que está en nosotros es una pequeña porción de la divinidad». Estos convencimientos de Diógenes ocasionaron que Aristófanes lo ridiculizara, cuando en su comedia Las Nubes
$(230,627)$ se burló de la relación entre el aire y la mente humana, así como de Aire y Respiración, las nuevas divinidades.

Ya en Anaxímenes, antes que en Diógenes, estuvieron presentes huellas de la consonancia entre el universo y el alma, del paralelo entre el macrocosmos y el microcosmos, de acuerdo con la versión que ofrece Aecio:

El milesio Anaximenes, hijo de Eurístrato, declaró que el principio de las cosas existentes es el aire, pues de él se generan todas las cosas $y$ en él se disuelven. "Exactamente igual que nuestra alma -dice-, al ser aire nos mantiene cohesionados, así también el aliento [o soplo] y el aire abarcan a todo el cosmos». Aire (aér) y aliento (pneûma) se toman como sinónimos. $(I, 3,4)$

Este pasaje ha generado polémica entre los especialistas acerca de si son o no palabras textuales de Anaxímenes ${ }^{6}$. Sin embargo, lo que resulta claro es que el aire, además de ser el principio universal y lo divino, es también la materia del alma humana. Con posterioridad, los filósofos estoicos abrevan el concepto «soplo» o pneûma con el significado de «espíritu». Cuestión que influirá, a su vez, en el Cuarto

\footnotetext{
6. Este tema puede ampliarse en W. K. C. Gutthrie (1991, 133), y J. Longrigg (1964, 1-4).
} 
Evangelio de San Juan, donde los términos «Espíritu», «soplo» y «viento» se usan indistintamente.

No se trata de acrecentar los ejemplos en donde el aire se manifieste como elemento universal y divino, sino en mostrar cómo la filosofía se retroalimenta de las creencias populares y la religión. Eso es importante para efectos de no adelantar prematuramente a autores con teorías científicas y técnicas que no corresponden con su mentalidad, pues lo que pretendieron fue argumentar racionalmente en torno a su visión teológica del universo. Un problema para nosotros acontece cuando se hace referencia al concepto "mito», que por muchos siglos se lo ha rebajado al nivel de «fábula», «ficción» o «superstición». El mito quiere decir a nivel etimológico «narración», «historia», «relato», no habiendo en esto un sentido negativo. Para los griegos los mitos eran parte esencial de su civilización y constituían tradiciones verdaderas, sagradas, revelaciones primordiales y modelos por seguir. El mito no fue entendido como ajeno al lógos, como en un momento dado lo hizo Jenófanes (B 11, B 12, B 14), el crítico de los grandes poetas, y después Tucídides (I, 21), quien evalúa a los mitos como algo «fabuloso» y «sin pruebas», en oposición a cualquier realidad. Tiempo más tarde, el judeocristianismo relegó los mitos al reino de las bellas mentiras paganas. Entre los griegos los mitos estaban menos enmascarados que entre nosotros, donde la ciencia, la técnica y la lógica aparentemente los han removido. La mitología significa la primera forma de explicación de cómo ha venido a la existencia la realidad total, ya sea del cosmos o de seres individuales, costumbres, instituciones, etc. El mito principal es el cosmogónico, pues hace posible a todas las demás narraciones y trata sobre las hazañas, por lo común dramáticas, de seres sobrenaturales que intervinieron para efectos de que cada uno de nosotros esté aquí, tenga un propósito y un destino. Por eso, los pioneros de la filosofía estuvieron preocupados por la cosmogonía, en función de sus necesidades teológicas. Si los griegos no contaron con libros sagrados o con una oficialidad institucional que dictaminara las verdades religiosas, eso no fue impedimento para que sus relatos repercutieran sobre sus preclaros pensadores. La filosofía griega se derivó de la mitología, cuando a las divinidades se les otorgó una dimensión más abstracta, especulativa o metafísica mediante «principios» inherentes a la naturaleza.

El Aire de Anaxímenes posee no sólo las cualidades de los seres divinos (como ya lo había planteado Anaximandro al respecto de lo Ilimitado), sino también es llamado 
directamente «dios» (theós). Así lo hace constar, escandalizado, el romano Cicerón :

Después Anaximenes estableció que el aire es dios y que éste es engendrado, inmenso, infinito y siempre en movimiento, como si el aire sin forma alguna pudiera ser dios, cuando corresponde no sólo que dios tenga alguna forma, sino que debe ser la más bella, o como si no tuviera que morir todo lo que ha nacido. (Sobre la naturaleza de los dioses I, 10, 26)

En este pasaje Cicerón pudo no haber entendido plenamente el pensamiento de Anaxímenes, al señalar que el aire es «engendrado», a menos que se haya derivado del Caos. Sin embargo, no existen fragmentos que lo atestigüen y más bien Aristóteles (Física, III 4, 203b), de mayor autoridad, había hablado de Anaximandro y «la mayoría de los físicos», donde probablemente incluía también a Anaxímenes, para referirse a un «principio» caracterizado por «lo divino», «inmortal e imperecedero».

Anaxímenes realiza una descripción cosmogónica en la que la religión y la filosofía son indisociables. La referencia la hace Hipólito, que aunque está más alejado temporalmente de Anaxímenes que Cicerón, se justifica en una fuente más confiable como Teofrasto, partidario de Aristóteles:

Anaxímenes... dijo que el principio es aire infinito, a partir del cual se generan las cosas actuales, pasadas $y$ futuras, y los dioses y las cosas divinas, y lo demás, de las cosas que proceden de aquél. (Refutación de todas las herejías I, 7, 1)

El Aire de Anaxímenes engendra las generaciones de los dioses mitológicos y los cuerpos más simples como el agua, la tierra y el fuego, así como otros de no menor envergadura, como el viento, las nubes y las piedras ${ }^{7}$. Al respecto de estos últimos queda claro que se forjan mediante el doble proceso de enrarecimiento y condensación, pero no hay sugerencia de cómo son producidas las deidades y «las cosas divinas» (quizás las que no son inmortales pero sumamente duraderas). Habría que presuponer en Anaxímenes que los seres sobrenaturales en su primera camada se gestaron como en Hesíodo (Teogonía 124-132), por partenogénesis ( «sin el deseable amor») a partir del Aire. De ese modo fue como Gea

7. Resulta esclarecedora la aportación de $\mathrm{Ch}$. Kahn (1960, 133 y 156), en la dirección de que la terminología empleada por los milesios en cuanto a la concepción de la tierra, el agua, el aire y el fuego es la de «miembros» o «porciones» del cosmos, y que Anaxímenes adjuntó el viento, las nubes y las piedras entre los «productos primarios» del aire. 
dio a luz, «a partir de ella misma, al estrellado Urano, a las grandes Montañas, y a los Mares, de impetuosas olas». Aunque en las creencias populares las divinidades se ligan con los elementos y Gea se asocia con la tierra, Océano y Tetis con el agua, Hefesto con el fuego, y el aire con Céfiro, Bóreas y Noto, lo que pudo haber incidido con exactitud en las reflexiones teológico-filosóficas de Anaxímenes queda nebuloso.

\section{Conclusión}

La teología ha sido crucial para los primitivos pensadores griegos y no debe admitirse que sólo fue un asunto de interés para los grandes poetas. En las visiones religiosas y filosóficas sobre el cosmos se puede rastrear una estela de lo divino y sobrenatural como factor explicativo de los fenómenos. Un avance de los milesios no fue tanto en carecer de la envoltura narrativa-poética de los mitos, sino el desprenderse de la característica mítica que requiere de causas particulares para explicar los sucesos. Zeus tira el rayo, Poseidón propaga los vientos marinos tormentosos, o las Parcas determinan los hilos de la vida de los mortales; es decir, son seres personales que actúan en cada caso de manera distinta para los acontecimientos individuales. Los milesios, en cambio, saltaron hacia explicaciones genéricas a partir de «principios» divinizados e ingénitos a la totalidad de las cosas, ya sea el Agua, lo Ilimitado o el Aire. Sin embargo, nunca desecharon directamente la explicación mitológica, pues no hay ningún pasaje en que ésta sea invalidada. Más bien, en Tales aparecen expresiones como «todo está lleno de dioses», en Anaximandro lo Ilimitado posee atributos superiores a un Zeus y en Anaxímenes el Aire es nombrado abiertamente como «dios». Por tanto, puede asentarse que las creencias míticas, mágicas y proverbiales están no sólo latentes, sino también explícitas en esta filosofía griega arcaica. Para nuestro tiempo, donde los mitos están más encubiertos y solapados bajo el lenguaje científico y racional, resulta más difícil detectar la injerencia que han tenido sobre la filosofía.

En el albor del filosofar griego sus teorías no son incompatibles con los dioses o lo divino, por lo que habría que descartar una tendencia jonia hacia el ateísmo. Hay que minimizar en ese período la revolución en el pensamiento desde un plano puramente racional, queriendo ver un salto completo del mito al lógos. Las narraciones religiosas de los tiempos antiguos no poseían las connotaciones negativas que adquirieron siglos después, en las que los mitos eran una forma de conocimiento explicativo de la realidad en su conjunto, una 
primitiva metafísica, capaz de dar cuenta de cómo los seres advinieron a este mundo. Asumir que el pensamiento mítico es un período rebasado, es una interpretación heredada de Hegel, para quien el Espíritu se supera históricamente en etapas de ascenso hacia el concepto, de la religión a la filosofía. Otro aspecto que ha incidido en interpretar los inicios del pensar filosófico de manera des-teologizada es la perspectiva de Aristóteles, el autor más antiguo en ofrecer un recuento de ese período y que menospreciaba los «sofismas» de la mitología. Además, su vara lógica y científica, junto a su intención de probar su propia teoría de la cuádruple causación, le impidió comprender el punto de vista teológico que sobre el universo plantearon los primitivos filósofos jonios. En los milesios puede apreciarse una necesidad por fundamentar racionalmente sus creencias religiosas. La cosmogonía es su principal preocupación, como en una doctrina mítica el relato cosmogónico es el más importante, pues estructura o hace posibles todos los demás.

En Tales, el pionero de la filosofía, el Agua, la vida en todas las dimensiones cósmicas, los dioses, el alma y el automovimiento constituyen la médula que posibilita los fenómenos. Se trata de un hilozoísmo no disonante de las religiones animistas y politeístas.
En esa dirección se circunscribe Anaximandro, en donde su arché, el ápeiron, es el principio universal, como entidad viviente, divina, gobernante cósmico y propiciador de justicia. De una mezcla confusa y caótica de contrarios, éstos se separan y conforman todas las cosas. Otros aspectos comunes los presenta Anaxímenes, al proponer el Aire como arché, con cualidades de ser infinito, móvil, con vida, divino y conectado con todos los cuerpos vivientes, ya sean cuerpos celestes $\mathrm{u}$ organismos terrestres, por medio de la respiración. Sus planteamientos sobre las propiedades sobrenaturales del aire son indesligables de los mitos y creencias populares.

\section{Bibliografía}

Agustín de Hipona (2007), Ciudad de Dios. Libros I-VIII. Madrid, Gredos.

Aristóteles (1988). Acerca del Alma. Madrid, Gredos.

(1993). Física. Buenos Aires, Editorial Biblos.

Gredos.

(1990). Metafísica. Madrid,

Burnet, J. (1930), Early Greek Philosophy. London.

Cherniss, H. (1991), La crítica aristotélica a la filosofía presocrática. México, Universidad Nacional Autónoma de México.

Diles, H. (1969), Die Fragmente der Vorsokratiker: griechisch und deutsch. Zurich: Weidmann. 
Enuma Elish. Poema babilónico de la creación. (2008), Madrid, Editorial Trotta.

Gomperz, Th., Pensadores griegos. Una historia de la filosofía antigua, vol. I. Barcelona: Editorial Herder, 2000.

Guthrie, W. K. C. (1991), Historia de la filosofía griega, I. Los primeros presocráticos y los pitagóricos. Madrid, Gredos.

Heródoto (1979), Los nueve libros de la historia. México, Editorial Cumbre.

Hesíodo (1997), Teogonía. Trabajos y dias. Escudo. Certamen. Madrid, Alianza Editorial.

Homero (1991), Iliada. Madrid, Gredos. (1993), Odisea. Madrid, Gredos.
Jaeger, W. (1992), La teología de los primeros filósofos griegos. México, Fondo de Cultura Económica.

Kahn, Ch. (1960), Anaximander and the Origins of Greek Cosmogony. New York.

Longrigg, J. (1964), «A Note on Anaximenes' Fragment 2 (Diles/Kranz)», Phronesis, IX, I, 1-4.

Los filósofos presocráticos (1994), 3 vols. Madrid, Gredos.

Platón (1985), Diálogos, 7 vols. Madrid, Gredos.

Sagrada Biblia (1950). Buenos Aires, Nueva Edición Guadalupana.

Tucídides (1990-1992), Historia de la Guerra del Peloponeso. Madrid, Gredos. 
